\title{
A UNIQUE AUREUS OF FAUSTINA II WITH THE LEGEND MATER CASTRORUM FROM A LATE ROMAN AREA OF HOARDS IN THE SOUTHERN BALTIC REGION
}

\begin{abstract}
The unique pierced aureus of Faustina II comes from a pre-2016 find from the locality Stygajny in northern Poland. The region to the east of the Vistula delta is known for its remarkable concentration of Late Antique hoards, among them, the 5th century AD solidus deposits found at Trąbki Małe (German, Klein Tromp), the largest to be recorded so far in the Baltic area. This borderland zone of Germanic and Balt settlements evidently played a crucial political role during $3 \mathrm{rd}$ - 5th centuries AD. The aureus of Faustina II, presumably entered the region with a great mass of gold coin passing to the Gothic territory around AD 250 in a period of a mounting wave of Roman-Barbarian military conflicts. The hole pierced on the obverse above the head of the empress is commonly noticed on most aurei found on the territory identified with Gothic societies. Our coin belong to the relatively large group of unique Roman gold coins and medalions recorded in the Barbaricum, in contexts suggesting ritual practices, something that is rarely observed on the territory of the Roman Empire.

Keywords: aureus, Faustina II, Baltic area, hoards.
\end{abstract}

$\mathbf{T}$ he Museum of Archaeology and History in Elbląg in northern Poland has in its collections, since 2016, a unique aureus of Marcus Aurelius struck for Faustina the Younger. ${ }^{1}$

\footnotetext{
1 This text was written within the project Finds of Roman Coins in Poland and from Lands Connected with Poland financed from the Ministry of Science and Higher Education National Programme for the Development of Humanities, grant no. 0047/NPRH2/H11/81/2012. I am indebted for their helpful input to prof. Michael Speidel, dr. hab. Adam Cieśliński, dr. hab. Arkadiusz Dymowski, dr. Helle Horsnæs, dr.
}

\section{Aleksander Bursche}

University of Warsaw

abursche@yahoo.com

DOI: $10.14795 /$ j.v7i1_SI.478

ISSN 2360 - 266X

ISSN-L 2360 - 266X 


\section{DESCRIPTION}

An aureus of Marcus Aurelius struck for Faustina the Younger, Rome mint, AD 174175, weight: $7.23 \mathrm{~g}$ (Fig. 1), die-axis: 6.

Av.: FAVSTINA[E] AVGVSTAE

Bust of Faustina right, draped, hair fastened in bun on back of head.

Rv.: MATRICASTRORVM

Female figure standing left, veiled and draped, holding in right patera over flaming garlanded altar, at left - box of incense, two legionary standards to left, the left topped with a statue of Victory.

Note: a fragment of the flan cut off prior to striking; pierced from the obverse over the head of the empress; in prime condition, almost without traces of wear.
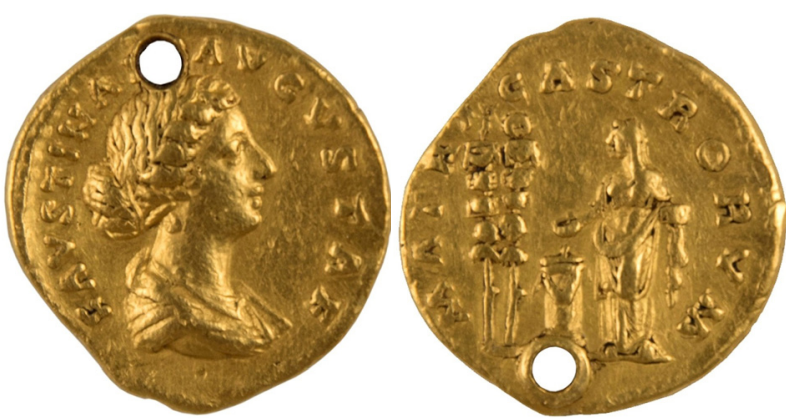

Fig. 1. Stygajny, Braniewo district, aureus of Marcus Aurelius (for Faustina the Younger), Museum of Archaeology and History in Elbląg (photo A. Grzelak), scale 2:1.

The aureus type described here is unique, not listed in the main corpora of RIC and OCRE. On the other hand, analogous bronze coins have been recorded, with the additional legend SC on the reverse: sestertii - RIC, 1661; and asses - RIC, 1662; some with a variant with three military standards on the reverse: RIC, 346, 1159-1660 (Fig. 2;). ${ }^{2}$ Furthermore, the Cabinet des Médailles in Brussels has an aureus from the Du Chastel Collection (Fig. 3), with an almost identical pattern but struck with another reverse die, with the obverse legend in the nominative case: FAVSTINA AVGVSTA. ${ }^{3}$

Marek Jagodziński, dr. Kyrylo Myzgin and dr. Kalina Skóra.

2 CF. ALSO THIRON 1967; BOATWRIGHT 2003.

3 THIRON 1967; CALLATAŸ/HEESCH 1999, 119, no.
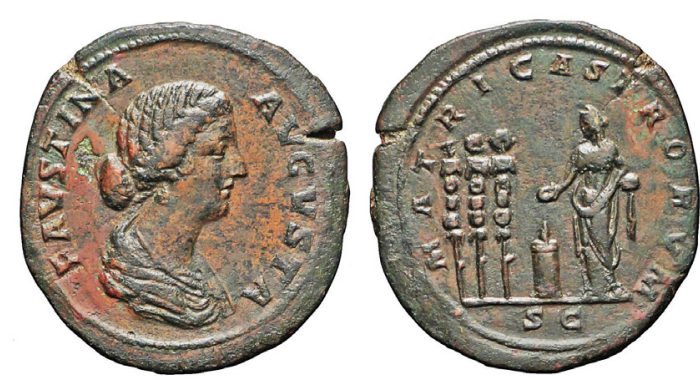

Fig. 2. Sestertius of Marcus Aurelius (for Faustina the Younger) from 161-176, after Numismatica Varesi, Cesare Auction, lot 685 (07.04.2018), scale 2:1.

The female figure depicted on the reverse is most likely Pietas, the personification of piety. ${ }^{4}$

The weight of this coin $-7.23 \mathrm{~g}-$ is thought-provoking. It is similar to the weight of an aureus which survives in mint condition in the Cabinet des Médailles in Brussels - 7. 31 g. After Nero's monetary reform of AD 6365 the Roman pound (libra) would yield 45 aurei rather than the standard 42 introduced through the reform of Augustus. Thus, Nero had reduced the mean weight of the aureus from $7.79 \mathrm{~g}$, as it was in the early days of the Principate, to ca. 7.28 g. $^{5}$ During the $3^{\text {rd }}$ century its weight would be reduced even further.

In antiquity the coin flans were usually cast, and on occasion their weight might considerably exceed the set standard. When this happened, the edge of the flan was trimmed; this is exactly the case of our coin.

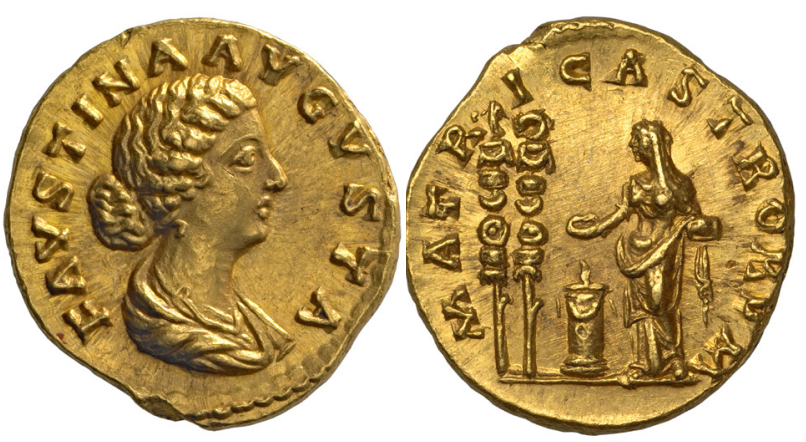

Fig. 3. Aureus of Marcus Aurelius (for Faustina the Younger), Cabinet des Médailles, Brussels, the Du Chastel Collection (photo Ch. Weber), scale 2:1.

648, Pl. 33.

4 SZAIVERT 1986, 71; cf. SPEIDEL 2012, 145.

5 BUTCHER/PONTING 2014, 251-253. 
THE TITLE OF MATER CASTRORUM AND THE DATE OF ISSUE

The title mater castrorum (Mother of the Camp) in the dative case seen on the reverse appeared in Roman coinage and epigraphy in relation to Faustina the Younger. This title, at once prestigious and religious, was granted to the empress in June AD 174 when she accompanied her husband to Sirmium (today, Sremska Mitrovica in Serbia), the capital of the Roman province of Pannonia Inferior. ${ }^{6}$ Marcus Aurelius was at that time on the march against Germanic tribes living beyond the Danube (Marcomanni, Quadi) and the Sarmatian Iazyges during the so-called Marcomannic Wars. ${ }^{7}$

Consequently, we may date our coin to a relatively narrow period during the final years of Faustina II's life, between June AD 174 and the end of $\mathrm{AD} 175$ since the empress died in the winter of $\mathrm{AD} 175 / 176$, in southern Cappadocia, at the foot of Mount Taurus, in a village later renamed Faustinopolis in her honour. ${ }^{8}$ This is one of the few cases when one can pinpoint the time of issue of coins under Marcus Aurelius with the bust of Faustina the Younger. It could prove useful when refining the chronology of at least a part of other coins minted for the empress.

An analogous reverse legend, paired with a different image, was used on posthumous coins minted in AD 176-180 to commemorate the great empress, namely: aurei, ${ }^{9}$ denarii, ${ }^{10}$ and sestertii. ${ }^{11}$ On the coins belonging to this type Faustina is represented draped, seated left, holding Phoenix on globe in right outstretched hand, cradling a sceptre in her left; two or three military standards before (Fig. 4). To date, this is the only aureus type recognized that has three military standards, but one may surmise that there may have been gold coin which may have the same

\footnotetext{
6 BIRLEY 1993, 178, 254; BOATWRIGHT 2003, SPEIDEL 2012, 140-147.

7 BIRLEY 1993, 159-183, 249-255; FRIESINGER/ TEJRAL/STUPPNER 1994.

8 cf. BIRLEY 1993, 191-192, 228; PRIWITZER 2008; SPEIDEL 2012, 147-151; LEVICK 2014.

${ }^{9}$ RIC III, 751.

${ }_{10}$ RIC III, 752-753.

11 RIC III, 1711-1712.
}
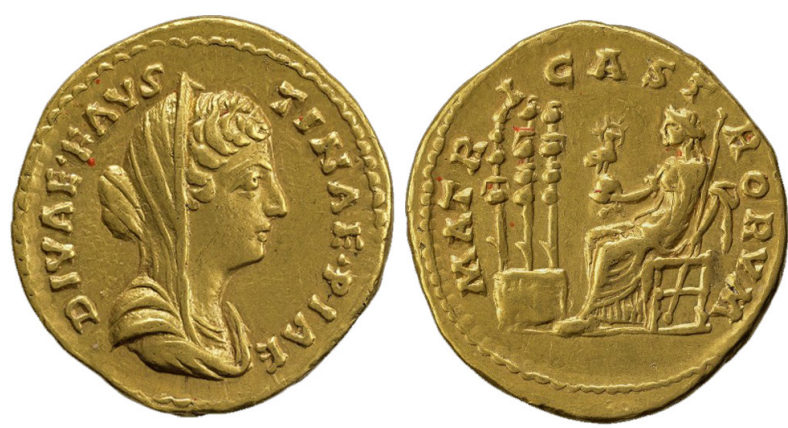

Fig. 4. Aureus of Marcus Aurelius (for Faustina the Younger) from 176-180, British Museum, London (after OCRE), scale 2:1.

reverse design as noted earlier, the figure on the reverse of the aureus under discussion is presumably Pietas sacrificing over a flaming altar, with military standards nearby (signa militaria), the most important symbols of the Roman army. The title mater castrorum and of Faustina's sojourn with the emperor and his army played an important role in cultivating and keeping alive the dynastic tradition, which was supposed to have a religious character. It is worth taking into consideration that Annia Galeria Faustina Minor was one of the central figures of the Nerva-Antonine dynasty, the youngest daughter of Antoninus Pius and Faustina the Elder, married in AD 145 to her cousin Marcus Aurelius whom her father had adopted and designated as the future emperor. She bore him at least fourteen children, including the future emperor Commodus. ${ }^{12}$ M.A. Speidel has recently discussed the origin of the title mater castrorum in this context exhaustively and competently by so there is no need to expand upon it here. ${ }^{13}$

Since the times of Faustina the Younger the title started to appear on coins of empresses during the Crisis of the Third Century, when the troops took to deciding who was to be proclaimed emperor. ${ }^{14}$ For the last time the title mater castrorum was used on a medal issued by Maria Theresa in 1743, evidently inspired by the Roman tradition of predecessor empresses (Fig. 5). ${ }^{15}$

\footnotetext{
12 cf. BIRLEY 1993, 247-248; BOATWRIGHT 2003 , 252-253, 266; PRIWITZER 2008; LEVICK 2014.

13 SPEIDEL 2012.

14 CALABRIA 1989.

15 SPEIDEL 2012, 130-131.
} 

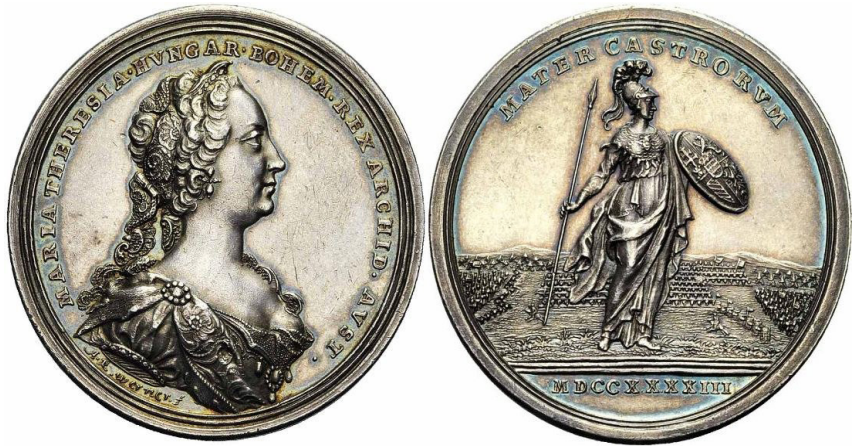

Fig. 5. Medallion of Maria Theresa as mater castrorum, 1743, after Jean Elsen \& ses Fils S.A., Auction 109, lot 1818 (18.06.2011), scale 1:1.

\section{PROVENANCE}

The aureus of interest here is a metal detector find retrieved in the village of Stygajny, Braniewo district, on the northern margin of the valley slope of the Wałsza river near its confluence with the Pasłęka. The exact find spot has not been confirmed through archaeological methods. Due to the easily defensive character of the area, a series of fortifications - trenches with numerous reinforced concrete bunkers - were built during the 1920s and 1930s along the northern edge of the Wałsza Valley and the eastern margin of the Pasłęka Valley.

During a much earlier period the two river valleys cutting deeply into the underlying moraine had influenced the settlements of the Roman period. Maps of settlements in the region reveal that the drainage basins of the Pasłęka and the Wałsza mark the eastern boundary of the archaeological Wielbark Culture, attributed to Gothic groups of population (Fig. 6). Farther to the east lies an obviously uninhabited area; the first habitation sites of the Dollkeim-Kovrovo Culture identified attributed to Baltic communities can only be found on the northern and eastern margins of the Górowo Heights.

In the area where the Faustina aureus came to light one notes a recorded concentration of finds of Late Roman gold coins and medallions, gold and silver jewellery, and fragments of a cut Late Antique silver plate. They belong to two solidus hoards discovered in close proximity, in the municipality of Trąbki Małe, Braniewo district, a finder's hoard identified with an itinerant goldsmith found in the region of Frombork, and an assemblage, or possibly more than one, recovered near Młoteczno, in the Braniewo district. The status of this latter find is still debated.

The two hoards of late Roman solidi (jointly over 140 items) came to light during the first half of the $19^{\text {th }}$ century at Trąbki Małe (Klein Tromp) on a hill known locally as Goldberg. The time of their deposition was dated to AD 430440. Together with the assemblage found at Mrzezino, Puck district, comprising reportedly ca. 150 solidi, ${ }^{16}$ the hoards from Trąbki are currently the largest deposits of Roman gold coins recorded in the Baltic Sea region. The one found in 1822 contained at least 97 coins, the earliest of them a pierced aureus of Gordian III (the only aureus in the hoard), followed by solidi of Valentinian emperors, mostly dated to the first half of the $5^{\text {th }}$ century. No is available on the remains of the container in which the hoard may have been buried. The other hoard came to light in 1837 and 1838, and very likely consisted of 43 solidi. It is likely moreover that a solidus of Theodosius II struck for Aelia Pulcheria acquired in the end of 1859 by the Coin Cabinet in Berlin also belonged to this second Trąbki hoard. Sometime later an alleged find of a solidus of Anastasius (AD 491-518) was attributed to the first Trąbki hoard but the chronological structure of the two deposits rules this out. ${ }^{17}$

The hoard recovered near Frombork contained some unfinished, damaged or repaired bronze bow brooches, e.g., type Schönwarling/Skowarcz and Dollkeim/ Kovrovo (Migration Period phase $\mathrm{C}_{3}-\mathrm{D}$ shapes), eight buckles of a type attributed to the Balts, a wire ring, two cast bronze rings, two beads (blue glass and jasper), a fragment of a Roman bronze vessel, a fragment of a

\footnotetext{
16 CIOŁEK 2007, 136, no. 225.

17 DAHMEN 2014. Also http://ikmk.smb.museum/ tray?lang=de and http://ikmk.smb.museum/map_ search?lang=de\&location_id=1236\&type=finding Accessed 4 August 2018.
} 


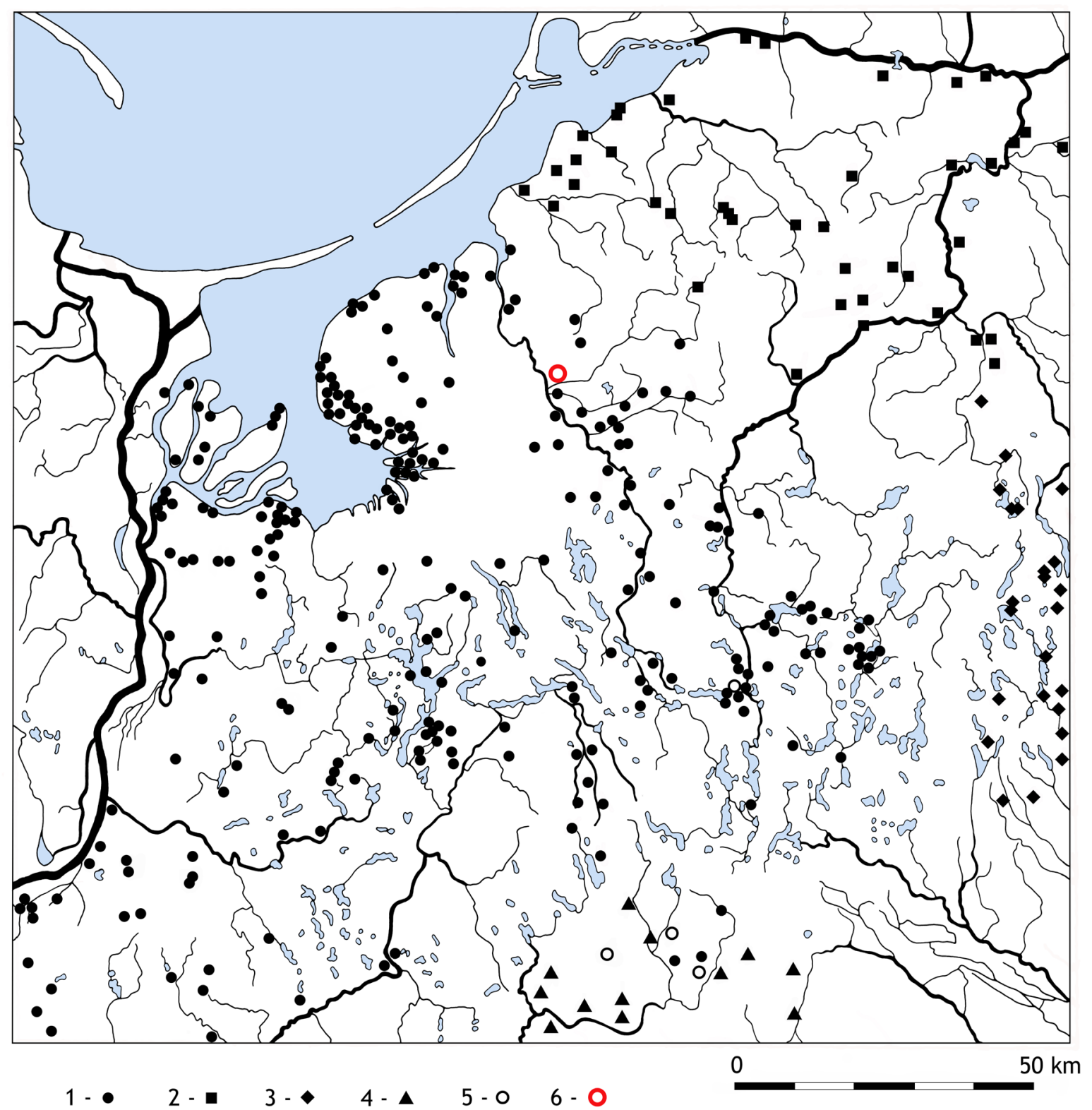

Fig. 6. Archaeological sites dated to the Roman period and the early Migration period (after CIEŚLIŃSKI 2009; CIEŚLIŃSKI 2010); key: 1 - Wielbark culture; 2 -Dollkeim-Kovrovo culture; 3 - Bogaczewo culture; 4 - Przeworsk culture; 5 - Przeworsk and Wielbark cultures; 6 - Stygajny, Braniewo district.

damaged, undetermined bronze object (a tool?), and a bronze bar. Out of the 32 coins belonging to this hoard 28 were denarii of the $1^{\text {st }}$ and the $2^{\text {nd }}$ centuries, the earliest of them a Titus issue from $\mathrm{AD}$ 80, the latest a Commodus issue from AD 192, a sestertius of Antoninus Pius, two unspecified bronzes, and a solidus of Theodosius II struck in AD 431 at Constantinople. Leather fragments were also recorded, presumably from a pouch originally containing the deposit. ${ }^{18}$

\footnotetext{
18 PEISER/KEMKE 1914; GODŁOWSKI 1972; 1981,
} 107-109; CIEŚLIŃSKI 2010, 168-170; ZAPOLSKA
The finds from Młoteczno display an even greater diversity. ${ }^{19}$ Recovered between 1873 and 1917, they include 17 or so gold and silver objects, more notably a gold radiateheaded bow brooch with three knops, set with garnets, type Nežin-SzilágysomlyóRegöly-Untersiebenbrunn (phase $\mathrm{D}_{1}$ - late $4^{\text {th }}$ century, the first quarter of $5^{\text {th }}$ century), two gold Scandinavian type neck rings, in the light of more recent evidence datable to the late $4^{\text {th }}$ century, a looped gold medallion

19 PEISER 1919; EBERT 1923, 159-172, PL. 3-8. 
of Constantius II (AD 335-336), a gold chain, gold bucket-shaped pendants, and a cut silver plate associated with the Europe-wide horizon of hacksilver. ${ }^{20}$ It is not entirely clear whether originally these objects had formed part of one, two, or even three subsequently ploughed out deposits, or had been placed into the ground together, in a site fulfilling a special function comparable to that of the central place at Gudme on Funen. ${ }^{21}$ One should nevertheless note that in the light of more recent studies their chronology is relatively narrow, confined to the last quarter of the $4^{\text {th }}$ century and the first quarter of the $5^{\text {th }}$ century at the latest.

Finally, a solidus of Theodosius II from AD 408-450 was found at Nałaby, Braniewo district. ${ }^{22}$ It is the easternmost find of a Late Roman solidus.

Summing up the remarks concerning the wider archaeological context of the aureus in question here, my conclusion is that the coin was deposited in a border zone between two cultures, on the north-eastern margin of the territory settled by the Goths. The settlement micro-regions which came into being here at the end of the $2^{\text {nd }}$ century and during the $3^{\text {rd }}$ century attest - particularly in the context of the assemblages from Frombork, Trąbki, and Młoteczno discussed above - to the emergence of a rich settlement centre in the Late Roman period at the mouth of the Pasłęka River, close to the border of the Balt territory. This centre was engaged in interregional exchanges and was in use until the onset of the Migration Period. ${ }^{23}$

\section{CIRCUMSTANCES OF INFLUX}

The prime condition of the aureus suggests that it was carried to the territory of the Barbaricum soon after minting. In this

20 GODŁOWSKI 1981, 78-80; ANDERSSON 1995; BURSCHE 1998a, 76-79, 182-183 and 237, No. 14; CIEŚLIŃSKI 2008, 120-123; 2010, 162-168; HILBERG 2009, 157-162; RAU 2013, 341, 343; KULAKOV 2014, 45-63.

21 Cf. HILBERG 2009, 161-163, Fig. 5.60; CIEŚLIŃSKI 2010, 165.

22 CIOŁEK 2007, 137, no. 229.

$23 \quad$ BITNER-WRÓBLEWSKA/WRÓBLEWSKI 2015; CIEŚLIŃSKI 2017. case the most likely circumstances would be the Marcomannic Wars waged by the Danube. Without a doubt a huge wave of secondcentury denarii entered the North as a result of this armed conflict. ${ }^{24}$ However, this scenario seems highly unlikely in the case of the aureus from Stygajny, although obviously it cannot not be ruled out altogether.

Unlike the denarii which form a vast pool on the territory of the Central and Eastern Barbaricum, finds of aurei from the period spanning the years after the Neronian reform of AD 63-65 and the final years of the Nerva-Antonine dynasty (?) are relatively rare. Moreover, they tend to be heavily worn, except for a very small group of relatively wellpreserved specimens (Figs. 7-8).

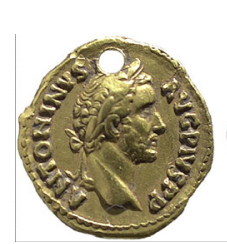

Fig. 7. Aureus, Antoninus Pius, AD 145-161; 7.29 g; the Stanisław August Poniatowski Collection, National Museum of the History of Ukraine, Kyiv (after BURSCHE/ WIĘCEK 2010), scale 1:1.

\section{$\mathrm{C}_{1}-\mathrm{C}_{2}$.}

Four aurei were found in grave 8 at Haßleben, Kr. Sömmerda in Thuringia: a Hadrian from 134-138, two Antoninus Pius from AD 145-161 and AD 151-152, and a Gallienus from AD 260-268; each of the first three display a hole. ${ }^{25}$ A burial identified at Gommern, Kr. Jerichower Land, in Saxony-Anhalt,

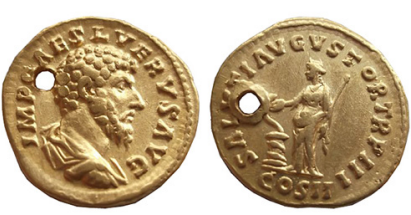

Fig. 8. Aureus of Marcus Aurelius (for Lucius Verus), AD 162-162, weight $7.3 \mathrm{~g}$ found near Berdychiv, Zhytomir district (Бердичів, Житомірська обл.), UA (after K. Myzgin; RGCB Online 122) scale 1:1.
24 BERGER, 1992, 157-159; 2008, 105; BURSCHE 1994, 472-475; 2004, 196-198, 2011, 69-71; LUCCHELLI 1998; WOLTERS 1999, 385-386; ERDRICH 2001, 127128; DYMOWSKI/MYZGIN 2014; DYMOWSKI 2019. 25 SCHULZ 1933, 4-12; LASER 2003a, 201-202, no. 1033. 
yielded an aureus of Trajan from AD 112-114 and gilded silver foil recognized as the mount of a shield-grip rivet, with a design probably impressed from a denarius of Severus Alexander. ${ }^{26}$ Both burials have been dated to the late phase $C_{2}$, at the very end of the $3^{\text {rd }}$ century AD.

The surviving inventory of a looted child's grave, a log coffin burial within a stone setting, identified at Ostrowite, Chojnice district, on the territory within the range of the Gothic cultures, included an aureus of Vitellius, interestingly enough, without a hole. Other grave goods included fragments of a glass beaker, a silver brooch, a strap end, and a brooch spring. The broad dating of this assemblage is phase $C_{1}$, in absolute terms, presumably the first half of the $3^{\text {rd }}$ century. ${ }^{27}$ At Stare Grochy, Białystok district, barrow IV of the so-called Rostołty type, ${ }^{28}$ an inhumation burial in a log coffin yielded a pierced aureus of Marcus Aurelius struck for Lucius Verus, AD 166-167. ${ }^{29}$ Similarly to other type Rostołty barrows, this grave may be assigned to phase $C_{1 b}-C_{2}$, more likely, judging by the spur type, the second half of the $3^{\text {rd }}$ century AD. ${ }^{30}$

A cremation grave attributed to the Cherniakhiv culture, included among the Gothic cultures, excavated in the municipality of Yosypivka I, L'viv district (Йосипівка I, Львівська область), held a cut fragment (са. 1/6) from a very heavily worn aureus of Nero (Fig. 9). ${ }^{31}$ Unfortunately, the only other grave goods in this inventory were fragments of pottery. Nevertheless, the dating of the origins of the Cherniakhiv culture to approximately

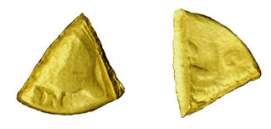

Fig. 9. Yosypivka I, L’viv district (Йосипівка I, Львівська обл.), fragment of aureus of Nero (after REVERA 2012), scale 1:1.
AD 250 may be proposed as the earliest time of of the coin from Yosypivka I. I shall return to the deposition

\footnotetext{
26 FRÖHLICH 2000, 204-205; LASER 2003b, 40, no. 1003.

27 WALENTA 2007.

28 On differentiating this type cf. CIEŚLIŃSKI 2014.

29 RIC III, 573.

30 RUSIN 2001a; RUSIN 2001b.

31 Cf. REVERA 2012.
}

this remarkable find below.

A heavily worn aureus of Antoninus Pius struck for Faustina the Elder after AD $141,{ }^{32}$ with three holes, found at Ejsbøl Mose, Haderslev Amt in Jutland is also relevant to the present discussion. Apparently reused to decorate a piece of military gear, most likely a belt, it ultimately ended up in a lake, like the rest of the equipment belonging to a Germanic detachment. ${ }^{33}$ The objects forming the assemblage from Ejsbøl Mose have been dated to phases $\mathrm{C}_{2}-\mathrm{C}_{3} \cdot{ }^{34}$

In a deposit of more than 250 denarii from the $1^{\text {st }}$ and the $2^{\text {nd }}$ centuries found at Jerzmanowice, Kraków district, in the Kraków-Częstochowa Upland, four gold coins had loops: an aureus of Claudius I struck during the reign of Nero, an aureus of Severus, a solidus of Valentinian I, and a gold imitation aureus of Maximian. Gold personal ornaments in the same assemblage include a crescenttype pendant with a granulated ornament of triangles and an axe-shaped pendant. ${ }^{35}$ The assemblage was assigned to phase $\mathrm{C}_{3}-\mathrm{D}$ or to the late $4^{\text {th }}$ century and attributed with some confidence to immigrants forced out from the territory of the Cherniakhiv culture by Hunnic invasions.

A heavily worn aureus of Nero from AD 65-66 surfaced in the distribution area of the Przeworsk culture at Zawada, Staszów district, near a cremation burial, no. 192, furnished for example with a terra sigillata vessel of potter Helenius of Westerndorf active during the reign of the Severan emperors. The dating of this inventory is phase $C_{1}$, presumably the first quarter of the $3^{\text {rd }}$ century AD (Fig. 10). Although the authors of this research have interpreted this coin as an element of a grave inventory, this is not entirely certain. ${ }^{36}$ On the other hand, interestingly enough, this particular aureus was not pierced.

\footnotetext{
32 RIC III, 395a.

33 HORSNÆS 2010, 74-75, 146, 169; BURSCHE 2011,

21 Fig. 18; 80-81.

34 ØRSNES 1988; ANDERSEN 2003.

35 DYMOWSKI 2007, 77, 2011, 223-224.

36 CHOMENTOWSKA/MICHALSKI 1992; KACZANOWSKI/MARGOS 2002, 361, NO. 898.
} 




Fig. 10. Zawada, gm. Połaniec, aureus of Nero (photo M. Dąbski), scale 1:1.
Asomewhat different picture is afforded by finds of aurei from the western region of the Barbaricum, i.e. Lower Saxony, Westphalia, and Jutland. The gold coins of Augustus and Tiberius found there may be attributed to the presence of the Roman army east of the Rhine ${ }^{37}$ An aureus of Tiberius struck at Lugdunum in AD 36-37 came to light at Bæk, Haderslev Amt in southern Jutland, in an elite inhumation burial dated to phases $\mathrm{B}_{1}-\mathrm{B}_{2 \mathrm{a}}$, thus, to the $1^{\text {st }}$ century $\mathrm{AD}^{38}$ The influx of aurei to this area presumably belongs to that early horizon. An unpierced aureus of Nero in almost mint condition came to light at Ginderup, Thy Herred, in north-western Jutland, in a remarkable deposit containing 31 denarii. ${ }^{39}$ It was found inside the settlement, underneath the floor of dwelling III dated to phase $B_{2}$. The denarii from this hoard span $125 / 120 B C$ and AD 74. This suggests that this particular, unpierced aureus was deposited at the end of the $1^{\text {st }}$ century AD or during the first half of the $2^{\text {nd }}$ century AD.

In contrast, on the territory of the Central and Eastern European Barbaricum the overwhelming majority of archaeological assemblages containing aurei from AD 64 to $\mathrm{AD} 192$ derive from contexts that can be dated to the mature phases of the Late Roman period, i.e. the second half of the $3^{\text {rd }}$ century $\mathrm{AD}$ and later. That is, except for the two uncertain grave assemblages known from Zawada and Ostrowite. Interestingly, the aurei in these two inventories were not pierced which suggests that in the first half of the $3^{\text {rd }}$ century the practice of making holes in gold coins was not yet in fashion.

To sum up, the above archaeological analysis seems to show that some contexts fail to confirm a $2^{\text {nd }}$-century influx of aurei to East-Central Europe.

\footnotetext{
37 BERGER 1992, 104-114.

38 KORTHAUER 1997; HORSNÆS 2010, 63, 146.

39 BJERG 2007, 41-55; HORSN/ÆS 2010, 52, 105-106.
}

The picture afforded by the archaeological data fully matches the findings from the analysis of numismatic sources. Hundreds of aurei spanning the reign of Nero (after his reform) and the late $3^{\text {rd }}$ century $\mathrm{AD}$ are documented in the territory occupied by Gothic societies, identifiable in the Late Roman period with the Wielbark and Cherniakhiv cultures, i.e. the territory between the southern Baltic seaboard to the northern Black Sea coast. The $21^{\text {st }}$ century, in particular, has brought a major increase in the number of such finds, the effect of widespread amateur metal detecting (Fig. 11). ${ }^{40}$ Since 2018, Dr. Kyrylo Myzgin (Кирилл Мызгин) has been recording such finds on an on-line portal developed at the Digital Humanities Laboratory of the University of Warsaw. ${ }^{41}$ The coins presumably entered the Barbaricum not as a result of trade but of political circumstances, through plunder, Roman tribute payments, annual subsidies and diplomatic gifts made to the barbarian power elites in exchange for military assistance, or for keeping the peace along the borders of the Empire. ${ }^{42}$ The largest group of these barbarian finds are aurei dated to AD 238-251, identified as plunder taken by the Goths from the imperial treasury after they had crushed the Romans and killed emperor Trajan Decius at Abrittus in AD 251, near today's municipality of Razgrad in Bulgaria. ${ }^{43}$

It seems that this great wave of aurei that entered the Barbaricum was accompanied by much earlier specimens, including our coin find from Stygajny. This seems confirmed by the find of the cut fragment of an aureus of Nero found in the burial at Yosypivka, attributed to the Cherniakhiv culture. This is because the horizon of cut aurei recovered from the territory of Gothic cultures, mostly from cemeteries, may be linked to the aftermath of the Gothic victory at Abrittus. The find from

\footnotetext{
40 MYZGIN 2017.

${ }^{41}$ Cf. http://rgcb.lach.edu.pl.

42 BURSCHE 1996a, 106-115, 125-128; MYZGIN 2016a; MYZGIN/FILATOV 2018.

43 BURSCHE 2013; 2016; MYZGIN 2016b; BURSCHE/ NIEZABITOWSKA 2018; BURSCHE/MYZGIN 2019.
} 


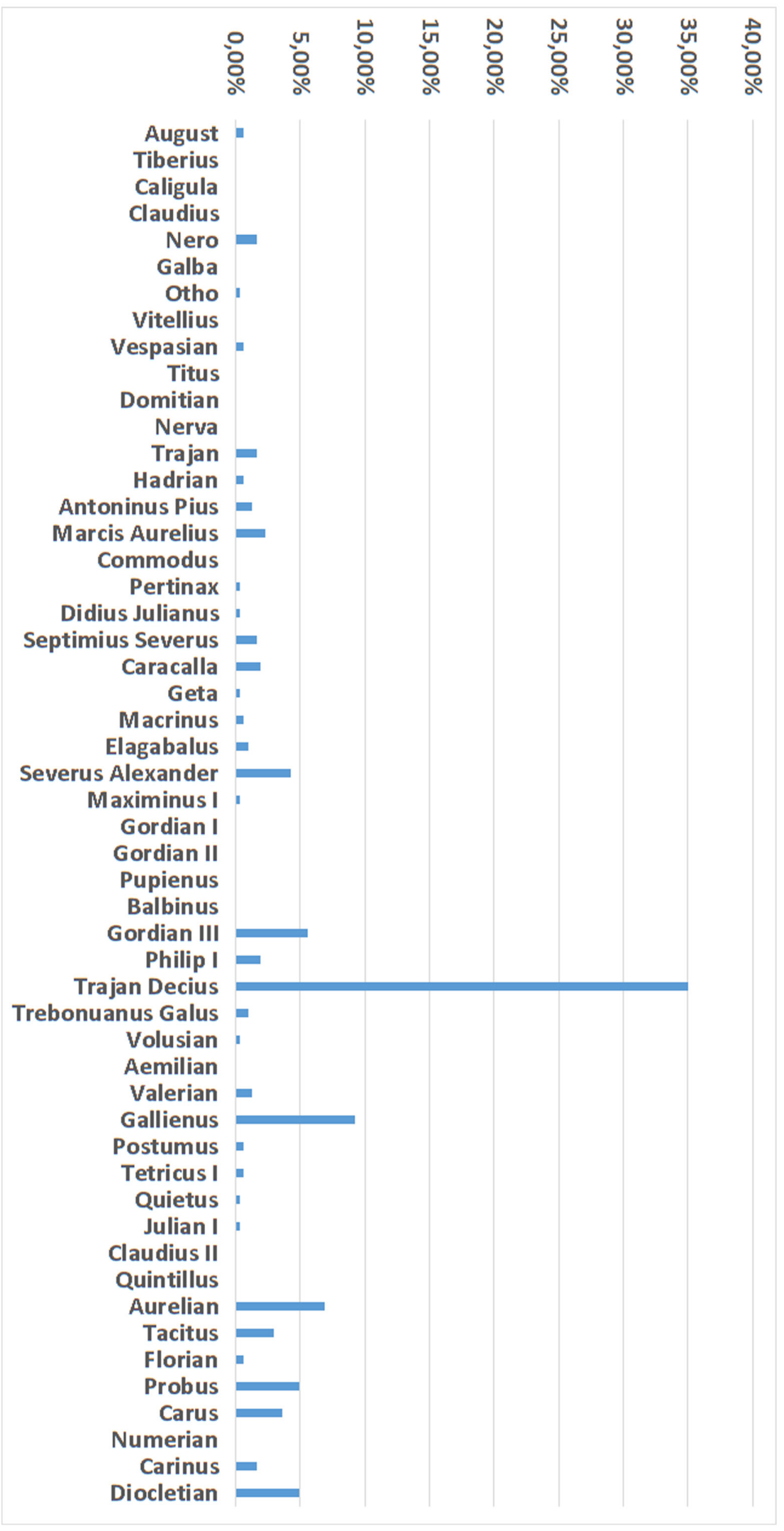

Fig 11. Finds of aurei from Ukraine (after: K. Myzgin).

Yosypivka I suggests that around AD 250 the imperial treasury still included aurei of Nero. Therefore, it is not unreasonable to conclude that gold coins of the Antonine emperors may have been found in that treasury as well.

However, it is not unlikely either that the first gold coins had passed into the hands of the Germanic elites even earlier, in the period of an intensified activity of the Goths and the presence of their detachments along the Danube, starting with the reign of Gordian III. At the same time, an influx dated earlier than the late AD 230s' seems hardly likely. On the other hand, aurei issued in the period AD 64-192 could have fallen into barbarian hands during a later period, even as late as the reign of Gallienus (see the case of the elite Haßleben burial) or the period of the Gallic usurpers.

Unfortunately for the present analysis, and due to reasons that are difficult to explain, very few larger hoards of aurei issued during the second and the third quarter of the $3^{\text {rd }}$ century $\mathrm{AD}$ have been recorded on the territory of the Empire. ${ }^{44}$ The percentage of $2^{\text {nd }}$ century issues in the aureus hoard found in 2007 at Fontainela-Gaillarde, in dep. Yonne in Burgundy comprising 249 coins, 44 CALLU/LORIOT 1990; KING 1993; BLAND/ LORIOT 2010; BLAND 2013. 
Tiberius to Probus, is on the other hand is quite remarkable. ${ }^{45}$ The largest aureus hoard recorded and published to date was the one with more than 2,600 coins found at Feldstraße at Trier, It ends with coins issued in AD 196 and includes many aurei from the reigns of Nero and Vespasian, some of them in prime condition, nearly unworn. ${ }^{46}$ This shows that even over a century after they were issued some gold coins found in hoards, and otherwise, might still be in an almost mint condition. This is because starting from the Severan dynasty in particular the participation of aurei in the regular, more intensive circulation continued to decline, unlike that of denarii and bronze denominations. ${ }^{47}$ Aurei started being treated as a source of precious metal and were often turned into jewellery and added to family treasures, handed down from one generation to the next. ${ }^{48}$ The Stygajny aureus could be one of such coins, which would explain its excellent preservation despite its late influx to the territory of the Barbaricum.

To wrap up the above discussion, the most likely conclusion would be that our aureus had left the territory of the Empire around AD 250 with the first larger wave of gold coin and entered the territory occupied by the Goths as a result of political contacts with the Rome.

\section{IN USE IN THE NORTH}

The Stygajny aureus has a hole made from the obverse above the head of the empress. Nearly all of the aurei and $3^{\text {rd }}$ century AD multipla found on the territory of the Barbaricum are pierced. The final quarter of the $3^{\text {rd }}$ century AD marks the beginning of the local fashion of adding suspension loops to coins and medallions. This fashion evidently reached a peak during the $4^{\text {th }}$ century $A D$, but some pierced solidi are still in evidence and continue to be recorded within the Barbaricum until the early years of the $6^{\text {th }}$ century. The introduction of the new fashion can be noted

\footnotetext{
45 GRICOURT/HOLLARD/BLET-LEMARQUAND 2014.

46 GILLES 2013.

47 BLAND 2013, 274.

48 KING 1993; LORIOT 2003.
}

in the end of the $3^{\text {rd }}$ century $\mathrm{AD}$ through a larger number of late aurei of Gallienus and Aurelian holed and an added loop. ${ }^{49}$

The aurei were almost invariably pierced from the obverse. Both the holes, and later the loops, are above the head of the emperor or a member of his family. This shows that the Barbarians attached a special role to the portrait depicted on the obverse. It is interesting to note that holes are also documented on cut aurei assigned to the Abrittus horizon. ${ }^{50}$ This shows that at least the aurei of Trajan Decius and his immediate predecessors were pierced soon after the imperial treasury was seized by the Goths. Specialised tools found in bog deposits in the same contexts with military gear suggest that some of the men in the Germanic detachments were skilled craftsmen, possibly goldsmiths. ${ }^{51}$ Their main duty would have been to perform armour repairs. Presumably, they are the ones who had perforated the aurei, possibly when the troop was still on the territory of the Roman Empire.

The other archaeological contexts of discovery of gold coins are typically richly furnished graves of men and women, and warrior burial inventories. ${ }^{52}$ The importance attached to Roman gold coins is confirmed by the graffito $\Gamma O Y N \Theta I O Y$ identified on the obverse of a pierced aureus of Postumus currently preserved at the National Ossoliński Institute in Wrocław. "Gunpijaz", presumably the owner of this particular aureus, may have been an officer of an ingentia auxilia germanorum unit attached to legio X Fretensis. ${ }^{53}$

It is a reasonable guess that Roman coins were used as symbols and identified their owners as members of the elite, described by the Roman authors as principes or reguli, or as Germanic seeresses. The coins

49 CALLU 1969, 429-430; 1991, 99-103; BURSCHE 1998a, 129-176; 2008; BURSCHE/WIĘCEK 2010; MYZGIN 2015.

50 BURSCHE 2013;2016; BURSCHE/NIEZABITOWSKA 2018.

51 DOBAT 2008, BURSCHE 2011, 22-23.

52 BEMMANN 2006, 2014; BURSCHE 2013; BURSCHE/NIEZABITOWSKA 2018.

53 DEGLER 2015. 
could have also served as marks of affiliation to a military detachment. The meaning that the barbarians attached to the portrait of the Roman emperors or of members of the imperial family, as symbols of the powerful Empire, may be similar to the value Native American chiefs in present-day USA and Canada give medals with the likenesses of British or French royalty, and somewhat later, of American presidents. ${ }^{54}$

\section{CONCLUSIONS}

This is not the first time that a unique specimen of Roman coinagehas been recovered on the territory of the Barbaricum. This is true in particular of gold coins known from a single specimen recovered from barbarian contexts, identified as such by their pierced condition or by an added suspension loop. ${ }^{55}$ In recent years a very large number of rare or one-off pierced aurei have come to light in Ukraine, on the territory of the archaeological Cherniakhiv culture identified with the Goths. They include rare coins of Gallienus, ${ }^{56}$ unique issues of usurpers Quietus, Julian I, ${ }^{57}$ and Aemilianus. ${ }^{58}$

What is more, an impressive number of medallions issued during the $3^{\text {rd }}$ and the $4^{\text {th }}$ centuries are known only from finds made east of the Rhine and north of the Danube. ${ }^{59}$ One may well wonder therefore if this is due to the knowledge of a mere fraction of the original number of coins and medals circulated, hoarded, deposited or dropped on both sides of the limes, or if this is an identified historical pattern.

It seems that, unlike the gold multipla, issued occasionally and mostly in provincial mints, that could have been partly reserved for the Germanic elite, ${ }^{60}$ the bulk of the regular official aurei from the central mint in Rome were confined in their circulation to the territory of the Empire. The situation

\footnotetext{
54 BURSCHE 1998a, 198-200.

55 BURSCHE 1980; BURSCHE/WIĘCEK 2010.

56 MYZGIN 2016a.

57 MYZGIN/FILATOV 2018.

58 Unpublished coin, pers. comm. K. Myzgin.

59 cf. BURSCHE 1996b; 1998a; 1998b; 2002; 2003; 2009.

60 BURSCHE 1998a; 2000.
}

after the defeat of Trajan Decius at Abrittus was definitely out of the ordinary (see the discussion above).

As a rule gold coins found their way back to the state treasury though the paying of taxes and many would be melted down in order to mint new aurei with a more current design and legend, in the $3^{\text {rd }}$ century also with a reduced weight. ${ }^{61}$ This presumably would explain the survival of rare aurei types outside the territory of the Empire, where these processes did not occur. Within the Barbaricum gold coins were used ${ }^{62}$ differently than within the Empire and found their way more often to deposits of a different character.

\section{ABBREVIATIONS \\ OCRE \\ http://numismatics.org/ocre/ \\ RIC \\ H. MATTINGLY, E.A. SYDENHAM, Roman Imperial Coinage, vol. III: Antoninus Pius to Commodus, London 1930.}

\section{REFERENCES}

ANDERSEN 2003

Andersen, H.Ch.H., New investigations in Ejsbøl bog. In: L. Jørgensen, B. Storgaard, L. Thomsen (ed.), The Spoils of Victory, The North in the Shadow of the Roman Empire (Copenhagen: Nationalmuseet), 246-255.

\section{ANDERSSON 1995}

Andersson, K., Romartida guldsmide i Norden III. Övriga smycken, teknisk analys och verstadsgrupper (Uppsala: Aun 21).

\section{BEMMANN 2006}

Bemmann, J., Zur Münz- und Münzerstazbeigabe in Gräbern der Römischen Kaiserzeit und Völkerwanderungszeit des mittelund nord-westeuropäischen Barbaricums, Studien zur Sachsenforschung 15, 1-62.

\section{BEMMANN 2014}

Bemmann, J., Mitteldeutschland und das Gallische Sonderreich 260-274: Eine Liebgewonnene These auf dem Prüfstand, Kölner Jahrbuch 47, 179-213.

\section{BERGER 1992}

Berger, F., Untersuchungen zu römerzeitli-

\footnotetext{
${ }^{61}$ DUNCAN-JONES 1994, 193-212; BLAND 1996; 83; 2013, 274-275.

62 Cf. also BURSCHE 2008.
} 
chen Münzfunden in Nordwestdeutschland (Berlin: Gebr. Mann).

\section{BERGER 2008}

Berger, F., Die Römischen Fundmünzen in Niedersachsen und Westfalen. Kontext und Funktionen. In: Bursche, A./Ciołek, R./Wolters, R. (eds.), Roman Coins outside the Empire. Ways and Phases, Contexts and Functions [Moneta 82] (Wetteren; Moneta), 105-111.

\section{BIRLEY 1993}

Birley, A. Marcus Aurelius. A Biography (London: Routledge).

\section{BJERG 2007}

Bjerg, L.M.H., Romerske denarfund fra jyske jernalderbopladser. En arkæologisk kulegravning (Aarhus: Universitetsforlag).

BITNER-WRÓBLEWSKA/WRÓBLEWSKI 2015

Bitner-Wróblewska A./Wróblewski W., Aestii Tacyta. Kim naprawdę byli?, Barbaricum 11, 65-78.

\section{BLAND 1996}

Bland, R., The development of gold and silver coin denominations, A.D. 193-253 In: C.E. King, D. Wigg (ed.), Coin Finds and Coin Use in the Roman World. The Thirteen Oxford Symposium on Coinage and Monetary History, 25-27.3.1993, A NATO Advanced Research Workshop (Berlin: Gebr. Mann Verlag), 63-100.

BLAND 2013

Bland, R., What happened to gold coinage in the 3rd c. A.D.?, Journal of Roman Archaeology 26, 263-280.

\section{BLAND/LORIOT 2010}

Bland, R./Loriot, X., Roman and Early Byzantine Gold Coins found in Britain and Ireland with an Appendix of New Finds from Gaul [Royal Numismatic Society Special Publication 46] (London: Royal numismatic Society).

BOATWRIGHT 2003

Boatwright, M.T., Faustina the Younger, „Mater Castrorum”. In: Frei-Stolba, R./ Bielman, A./Bianchi, O. (eds.), Les femmes antiques entres sphère privée et sphère publique (Bern : Lang), 249-268.

\section{BURSCHE 1980}

Bursche, A. Nieznana moneta Konstancjusza Chlorusa, Wiadomości Numizmatyczne 24, 2-3.

BURSCHE 1994

Bursche, A., Die Markomannenkriege und der Zufluß römischer Münzen in das Barbaricum. In: FRIESINGER/TEJRAL/ STUPPNER 1994, 471-485.

\section{BURSCHE 1996a}

Bursche, A., Later Roman-Barbarian Contacts in Central Europe. Numismatic Evidence, Studien zu Fundmünzen der Antike 11 (Berlin: Mann).

\section{BURSCHE 1996b}

Bursche, A., Najstarsze rzymskie medaliony z Barbaricum. In: A. Kokowski (ed.) Studia Gothica I. in memoriam Ryszard Wołągiewicz (Lublin), 85-100.

\section{BURSCHE 1998a}

Bursche, A., Złote medaliony rzymskie w Barbaricum. Symbolika prestiżu i władzy społeczeństw barbarzyńskich u schyłku starożytności [Światowit, Supplement Series A Antiquity, t. II] (Warszawa: Uniwersytet Warszawa).

\section{BURSCHE 1998b}

Bursche, A., Unikalny medalion Licyniusza I z północnej Małopolski. In: J. Kolendo (ed.), Nowe znaleziska importów rzymskich z ziem Polski I, Korpus znalezisk rzymskich z europejskiego Barbaricum, Polska, Suplement 1 (Warszawa: Uniwersytet Warszawa), 147-154.

\section{BURSCHE 2000}

Bursche, A., Roman gold medallions in Barbaricum. Symbols of power and prestige of Germanic elite in Late Antiquity. In: Kluge, B./Weisser, R. (eds.), Proceedings of $12^{\text {th }}$ International Numismatic Congress in Berlin (Berlin: Gebr. Mann Verlag), 28-45.

\section{BURSCHE 2002}

Bursche, A., Nieznany medalion cesarza Waleriana. In: B. Paszkiewicz (ed.) Moneta Mediævalis. Studia numizmatyczne i historyczne ofiarowane Profesorowi Stanisławowi Suchodolskiemu w 65. rocznicę urodzin (Warszawa: Uniwersytet Warszawa), 357-366.

\section{BURSCHE 2003}

Bursche, A., The Victoria Sarmatica of $\mathrm{AD}$ 340. In: von Carnap-Bornheim, C. (ed.), Kontakt - Kooperation - Konflikt. Germanen und Sarmaten zwischen dem 1. und dem 4. Jahrh. n. Chr. (Neumünster: Wachholtz), 407-413.

\section{BURSCHE 2004}

Bursche, A., Dalsze monety ze skarbu w Liwie, powiat Węgrów. Trzeciowieczne 
denary na terenach Barbaricum. In: Kaczanowicz. W. (ed.), Studia z dziejów antyku. Pamięci Profesora Andrzeja Kunisza (Katowice: Wydawnictwo Uniwersytetu Śląskiego), 192-205.

\section{BURSCHE 2008}

Bursche, A., Functions of Roman coins in Barbaricum of Later Antiquity. An antropological essay. In: Bursche, A./Ciołek, R./Wolters, R. (eds.), Roman Coins outside the Empire, Proceedings of the ESF/SCH Exploratory Workshop, Radziwiłł Palace, Nieborów (Poland), 3-6 September 2005 [Moneta 82] (Wetteren: Moneta), 395-416. BURSCHE 2009

Bursche, A., The unique gold Roman numismatics from the collection of the National Museum of Ukrainian History in Kiev, Polish Numismatic News 2009, 85104.

\section{BURSCHE 2011}

Bursche, A., Illerup Ådal 14: Die Münzen (Århus: University Press).

\section{BURSCHE 2013}

Bursche, A., The battle of Abrittus, the Imperial treasury and aurei in Barbaricum, The Numismatic Chronicle 173, 151-71.

BURSCHE 2016

[Бурше, А.], Битва при Абрите, императорская казна и ауреусы в Барбарикуме, Oium 5, 127-140.

BURSCHE/MYZGIN 2019

Bursche, A./Myzgin, K.V., Mid-3rd century Gothic invasions: coins and archaeology in Barbaricum, Journal of Roman Archaeology - in print.

BURSCHE/NIEZABITOWSKA 2018

Bursche, A./Niezabitowska, B., Two antique gold coins from Ulów in Roztocze. In: Niezabitowska-Wiśniewska B. et alii (eds.), Studia Barbarica, vol. II (Lublin: UMCS wydawnictwo), 248-267.

BURSCHE/WIĘCEK 2010

Bursche, A./Więcek, T., Roman gold coins and medallions, pierced or looped, from the collections of the National Museum of Ukrainian History in Kyïv, Wiadomości Numizmatyczne LIV, 193-224.

BUTCHER/PONTING 2014

Butcher, K./Ponting, M., The Metallurgy of Roman Silver Coinage. From the Reform of Nero to the Reform of Trajan (Cambridge: University Press).

\section{CALABRIA 1989}

Calabria, P., La leggenda "mater castrorum" sulla monetazione imperiale, Miscelanea Graeca e Romana 14, 228-233.

\section{CALLATAŸ/HEESCH 1999}

Callataÿ, F. de/Heesch, J. van, Greek and Roman Coins from the du Chastel Collection. Coin Cabinet of the Royal Library of Belgium (London: Spink).

\section{CALLU 1969}

Callu, J.-P., La politique monétaire des empereurs romain de 238à 311 , Bibliothèque des Ecoles Françaises d'Athènes et de Rome 214 (Paris: De Boccard).

\section{CALLU 1991}

Callu, J.-P., La perforation de l'or romain. In: Noeske, H.Ch./Schubert, H. (eds.), Die Münze. Bild - Botschaft - Bedeutung. Festschrift für Maria R.-Alföldi (Frankfurt am Main: P. Lang), 99-121.

\section{CALLU/LORIOT 1990}

Callu, J.-P./Loriot, X., L’or monnayé. II: La dispersion des aurei en Gaule romaine sous l'Empire, Cahiers Ernest Babelon 3 (Juanles-Pins: C.N.R.S.).

\section{CHOMENTOWSKA/MICHALSKI 1992}

Chomentowska, B./Michalski, J., Ciałopalny zespół z cmentarzyska z okresu wpływów rzymskich w Zawadzie, woj. tarnobrzeskie, Wiadomości Archeologiczne LII/1, 19911992, 99-110.

\section{CIEŚLIŃSKI 2008}

Cieśliński, A., Die spätrömische Kaiserzeit und die frühe Völkerwanderungszeit an der Passarge/Pasłęka. In: NiezabitowskaWiśniewska, B./Juściński, M./Łuczkiewicz, P./Sadowski, S. (eds.), The Turbulent Epoch. New Materials from the Late Roman Period and the Migration Period [Monumenta Studia Gothica V] (Lublin: Instytut Archeologii Uniwersytetu Marii CurieSkłodowskiej), 113-131.

\section{CIEŚLIŃSKI 2009}

Cieśliński, A., Kultura wielbarska nad Łyną, Pasłęką i górną Drwęcą, Pruthenia IV, 87115.

\section{CIEŚLIŃSKI 2010}

Cieśliński, A., Kulturelle Veränderungen und Besiedlungsabläufe im Gebiet der Wielbark-Kultur an Łyna, Pasłęka und oberer Drwęca [Berliner Beiträge zur Vor- und Frühgeschichte N.F. 17] (Berlin: Staatliche Museen zu Berlin). 


\section{CIEŚLIŃSKI 2014}

Cieśliński, A., Kopce kultury wielbarskiej z Mazowsza i Podlasia a tzw. typ rostołcki - próba nowego spojrzenia na związki cmentarzysk kurhanowych $\mathrm{z}$ północnej i wschodniej Polski, Wiadomości Archeologiczne LXV, 45-93.

CIEŚLIŃSKI 2017

Cieśliński, A., A cultural and ethnic border during the Roman and Early Migrations Period in Nord-East Poland. In: Semple, S./ Orsini, C./Mui, S. (eds.), Life on the Edge: Social, Religious and Political Frontiers in Early Medieval Europe [Neue Studien zur Sachsenforschung 6] (Wendeburg: Verlag Uwe Krebs), 211-224.

\section{CIOŁEK 2007}

Ciołek, R., Die Fundmünzen der römischen Zeit in Polen [Moneta 67] (Wetteren: Moneta).

DAHMEN 2014

Dahmen, K., Der Schatzfund von Klein Tromp in Ostpreußen (heute Trąbki Małe, Polen) Fundbeschreibung und -geschichte, Jahrbuch der Berliner Museen 56, 75-90.

DEGLER 2015

Degler, A., Aureus of Postumus with Owner's Graffito (Gounthios). In: Caltabiano, M.C. (ed.), Proceedings of XV International Numismatic Congress: Taormina 2015, t. II (Roma : Arbor Sapientiae), 723-726.

DOBAT 2008

Dobat, A. S., Werkzeuge aus kaiserzeitlichen Heeresausrüstungsopfern. Mit besonderer Berücksichtung der Fundplätze Illerup Ådal und Vimose (Århus: University Press).

DUNCAN-JONES 1994

Duncan-Jones, R.P., Money and Government in the Roman Empire (Cambridge: University Press).

DYMOWSKI 2007

Dymowski, A., Skarby monet rzymskich odkryte w ostatnim czasie na terenie Jury Krakowsko-Częstochowskiej, Wiadomości Numizmatyczne LI, 54-78.

DYMOWSKI 2011

Dymowski, A., Znaleziska monet rzymskich $\mathrm{z}$ terenu Polski rejestrowane w pierwszych latach XXI wieku. Aspekty źródłoznawcze (Zielona Góra: Eternum Wydawnictwo z Pracownia Humanistyczna).

DYMOWSKI/MYZGIN 2014

Dymowski, A., Myzgin, K., Inflow and redistribution of Roman Imperial denarii in the area of Przeworsk, Wielbark and Chernyakhiv cultures and in the Baltic islands in the light of chronological structure of coin hoards, Notae-Numismaticae Zapiski Numizmatyczne IX, 48-56.

\section{EBERT 1923}

Ebert, M., Neuerwerbungen des Prussia-Museums, Sitzungsberichte der Altertumsgesellschaft Prussia 24, 19091922, 149-172.

\section{ERDRICH 2001}

Erdrich, M., Rom und die Barbaren. Das Verhältnis zwischen dem Imperium Romanum und den germanischen Stämmen vor seiner Nordwestgrenze vor der späten Republik bis zum Gallischen Sonderreich [Römisch-Germanische Forschungen 58] (Mainz am Rhein : Von Zabern).

FRIESINGER/TEJRAL/STUPPNER 1994

Friesinger, H./Tejral, J., Stuppner, A. (eds.) Markomannenkriege. Ursachen und Wirkungen (Brno: Brno : Archeologický Ústav Akad. Věd. České Republiky).

\section{FRÖHLICH 2000}

Fröhlich, S. (ed.), Gold für die Ewigkeit - Das

Germanische Fürstengrab von Gommern,

Begleitband zur Sonderausstellung im Landesmuseum für Vorgeschichte Halle (Saale) (Haale: Landesamt für Archäologie Sachsen-Anhalt).

GILLES 2013

Gilles, K.-J., Der römische Goldmünzenschatz aus der Feldstraße in Trier [Trierer Zeitschrift Beiheft 34] (Trier: Rheinisches Landesmuseum Trier.

\section{GODŁOWSKI 1972}

Godłowski, K., Fromborski skarb z okresu wędrówek ludów, Komentarze Fromborskie 4, 57-69.

\section{GODŁOWSKI 1981}

Godłowski, K., Okres wędrówek ludów na

Pomorzu, Pomorania Antiqua X, 65-129. GRICOURT/HOLLARD/BLET-LEMARQUAND 2014

Gricourt, D./Hollard, D./Blet-Lemarquand, M., Donativa, thésaurisation et corpus monétaire: à propos d'aurei lyonnais inédits (275-281) du trésor de Fontaine-laGaillarde, Revue Numismatique 171, 195219.

HILBERG 2009

Hilberg, V., Masurische Bügelfibeln. 
Studien $\mathrm{zu}$ den Fernbeziehungen der völkerwanderungs-zeitlichen Brandgräberfelder von Daumen und Kellaren [Schriften des Archäologischen Landesmuseums Schleswig 9] (Neumünster: Wachholtz).

HORSNÆS 2010

Horsnæs, H.W., Crossing Boundaries. An Analysis of Roman Coins in Danish Contexts, Vol. 1: Finds from Sealand, Funen and Jutland. Publications of the National Museum [Studies in Archaeology and History 18] (Copenhagen: The National Museum of Denmark).

\section{KACZANOWSKI/MARGOS 2002}

Kaczanowski, P./Margos, U., Tabula Imperii Romani, M34 - Kraków (Frankfurt : Römisch-Germanische Kommission).

KING 1993

King, C.E., The role of gold in the later third century A.D., Rivista Italiana di Numismatica e Scienze Affini 95, 439-51.

\section{KORTHAUER 1997}

Korthauer, C., En ældre romertidsgrav med guldmønt fra Jylland, KUML. Årbog for Jysk Arkæologisk Selskab 1995-96, 113134.

KULAKOV 2014

Kulakov, V.I., Zespół dwóch złotych naszyjników/pierścieni z Młoteczna (Hammersdorf) i grzywny typu R300 w krajach nadbałtyckich, Pruthenia IX, 45-63.

\section{LASER 2003a}

Laser, R. (ed.), Fundmünzen der römischen Zeit in Deutschland, Abteilung XIII: Thüringen (Mainz: von Zabern).

LASER 2003b

Laser, R. (ed.), Fundmünzen der römischen Zeit in Deutschland, Abteilung X: Sachsen Anhalt (Mainz: von Zabern).

LEVICK 2014

Levick, B., Faustina I and II: Imperial Women of the Golden Age (Oxford: University Press).

\section{LORIOT 2003}

Loriot, X., Réflexions sur l'usage et les usagers de la monnaie d'or sous l'Empire romain, Revue numismatique 159, 2003, 57-74.

\section{LUCCHELLI 1998}

Lucchelli, T., La moneta nei rapporti tra Roma e l'Europa barbarica: aspetti e problemi [Publicazioni della Fazoltá di
Lettere e Filosofia dell’Universitá degli Studi di Milano 179] (Firenze: La Nuova Italia).

\section{MYZGIN 2015}

Myzgin, K.V. [Мызгин, К.В.], О времени появления ушек на золотых римских монетах в Барбарикуме, Stratum plus 6, 131-140.

MYZGIN 2016a

Myzgin, K.V. [Мызгин, К.В.], О находках ауреусов Галлиена на территории Украины, Стародавнє Причорномор'я XI (Одеса), 371-379.

\section{MYZGIN 2016B}

Myzgin, K.V. [Мызгин, К.В.], Новые находки ауреусов Гордиана III, Филиппа Араба и Траяна Деция на территории Украины, Oium 5, 141-145.

MYZGIN 2017

Myzgin, K.V. [Мызгин, К.В.], О хронологии поступления золотых римскиъ монет на территорию ЮгоВосточного Барбарикума. In: Е. Захаров (ed.) Нумизматические чтения Отдела нумизматики Государственного имсторического музея 2017 года (Москва), 35-40.

MYZGIN/FILATOV 2018

Myzgin, K.V., Filatov, D.A. [Мызгин, К.В., Филатов, Д.А.], Находки ауреусов узурпаторов III века на территории Украины, Стародавнє Причорномор'я XII (Одеса), 360-368.

\section{ØRSNES 1988}

Ørsnes, M., Ejsbøl I.: Waffenopferfunde des 4.-5. Jahrh. nach Chr. [Nordiske Fortidsminder, Seria B 11] (København: Det Kongelige Nordiske Oldskriftselskab).

\section{PEISER 1919}

Peiser, F.E., Der Goldfund von Hammersdorf, Mannus 10, 92-96.

\section{PEISER/KEMKE 1914}

Peiser, F.E./Kemke, H., Der Depotfund von Frauenburg, Sitzungsberichte der Altertumsgesellschaft Prussia 23/I, 58-79.

\section{PRIWITZER 2008}

Priwitzer, S., Faustina minor - Ehefrau eines Idealkaisers und Mutter eines Tyrannen. Quellenkritische Untersuchungen zum dynastischen Potential, zur Darstellung und zu Handlungsspielräumen von Kaiserfrauen im Prinzipat [Tübinger Althistorische Studien 6] (Bonn: Habelt).

\section{RAU 2013}


Rau, A., Where did the Late Empire end? Hacksilber and coins in continental and northern Barbaricum. In: Hunter, F./ Painter, K. (eds.), Late Roman Silver: the Traprain Treasure in Context (Edinburgh: Society of Antiquaries of Scotland), 339357.

REVERA 2012

Revera, Û. [Ревера, Ю.], Фрагмент ауреуса Нерона я пам'ятки иу Львівській області, Наукові студіi. Історико-краєзнавчий музей м. Вінникі 5, 245-251.

RUSIN 2001a

Rusin, K., Kurhany w Grochach Starych cmentarzysko elity plemiennej sprzed 1700 lat, Z otchłani wieków 56, 48-54.

RUSIN 2001b

Rusin, K., Groby i ich tajemnice. Wystawa Działu Archeologii Muzeum Podlaskiego w Białymstoku, Muzeum Podlaskie: Białystok,grudzień 2001 - marzec 2002 (Białystok: Muzeum Podlaskie).

\section{SCHULZ 1933}

Schulz, W., Das Fürstengrab und das Grabfeld von Hassleben [RömischGermanische Forschungen Band 7] (BerlinLeipzig: De Gruyter \& Co).

SPEIDEL 2012

Speidel, M.A., Faustina - mater castrorum. Ein Beitrag zur Religionsgeschicht, Tyche, Beiträge zur Alten Geschichte, Papyrologie und Epigraphik 27, 127-152.

\section{SZAIVERT 1986}

Szaivert, W., Die Münzprägung der Kaiser Marcus Aurelius, Lucius Verus und Commodus (Wien: Verlag der Österreichischen Akademie der Wissenschaften).

\section{THIRON 1967}

Thiron, M., Favstina avgusta, mater castrorvm: un aureus inédit, Schweizer Münzblätter 13-17, 1963-1967, 41-49.

\section{WALENTA 2007}

Walenta K., Mały książę" z Ostrowitego w gminie Chojnice, Łódzkie Sprawozdania Archeologiczne X (2006-2007), 101-120.

WOLTERS 1999

Wolters, R., NummiSignati.Untersuchungen zur römischen Münzprägungen und Geldwittschaft [Vestigia. Beiträge zur alten Geschichte 49] (München: Beck).

\section{ZAPOLSKA 2014}

Zapolska A., The coins from the goldsmith hoard of Frombork reconsidered, Zapiski Numizmatyczne - Notae Numismaticae IX, 95-116. 